\title{
Pengaruh Tax Avoidance Dan Mekanisme Corporate Governance Pada Manajemen Laba
}

\author{
Ni Putu Maysani ${ }^{1}$ \\ Fakultas Ekonomi dan Bisnis \\ Universitas Udayana, Indonesia. \\ Email: putumaysani97@gmail.com
}

\author{
I Gusti Ngurah Agung Suaryana ${ }^{2}$ \\ Fakultas Ekonomi dan Bisnis \\ Universitas Udayana, Indonesia.
}

\begin{abstract}
ABSTRAK
Manajemen laba adalah salah satu tindakan yang dilakukan manajemen untuk memanipulasi laba yang dihasilkan perusahaan untuk tujuan tertentu. Penelitian memiliki tujuan untuk menemukan bukti mengenai bagaimana pengaruh tax avoidance dan mekanisme corporate governance pada manajemen laba yang dilakukan manajer perusahaan. Populasi penelitian adalah perusahaan manufaktur yang terdaftar dalam BEI periode 2013-2017, kemudian sampel ditentukan dengan metode probability sampling dengan hasil sejumlah 12 perusahaan. Hasil penelitian memperlihatkan bahwa tax avoidance dan dewan direksi berpengaruh positif pada manajemen laba; dewan komisaris independen, komite audit, kepemilikan institusional, dan kepemilikan manajerial memiliki pengaruh negatif pada manajemen laba.
\end{abstract}

Kata Kunci: Manajemen Laba, Tax Avoidance, Corporate Governance.

\section{Effect of Tax Avoidance and Corporate Governance Mechanisms on Earnings Management}

\section{ABSTRACT}

Earnings management is one of the actions taken by management to manipulate profits generated by the company for certain purposes. The research aims to find evidence about how the influence of tax avoidance and corporate governance mechanisms on earnings management is carried out by company managers. The study population is a manufacturing company listed on the IDX for the period 2013-2017, then the sample is determined by a probability sampling method with the results of 12 companies. The results of the study show that tax avoidance and board of directors have a positive effect on earnings management; independent commissioners, audit committees, institutional ownership, and managerial ownership have a negative influence on earnings management.

Keywords: Earnings Management, Tax Avoidance,

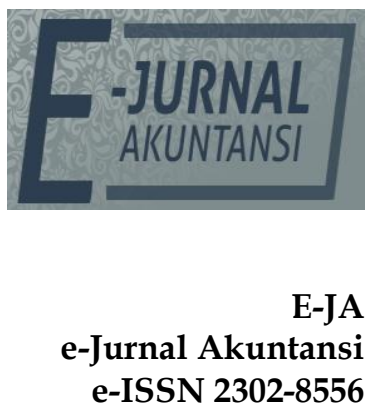

Denpasar, Vol. 28 No. 3

September 2019 Hal. 1886-1903

Artikel masuk: 18 Juni 2019

Tanggal diterima: 25 Juli 2019 


\section{PENDAHULUAN}

Laporan keuangan diterbitkan oleh perusahaan selama periode tertentu untuk memberikan gambaran hasil kinerja selama periode tersebut. Laporan keuangan merupakan jembatan penghubung antar pihak-pihak yang memiliki kepentingan. Laporan laba rugi merupakan salah laporan keuangan yang memberikan informasi mengenai hasil kinerja keuangan perusahaan, setelah dikurangi berbagai biaya dan beban, sehingga perusahaan dapat menentukan apakah mengalami keuntungan atau kerugian. Profit atau laba merupakan salah satu variabel yang biasanya digunakan untuk menilai kinerja para manajer. Informasi keuntungan dan kerugian dalam laporan laba rugi dapat digunakan pihak pemilik perusahaan untuk menentukan rencana selanjutnya dalam operasi perusahaan, hal inilah yang membuat manajer memiliki tanggungjawab untuk memberikan informasi laba yang baik.

Manajer dan pemilik saham memiliki ambisi tersendiri untuk mewujudkan keinginan mereka. Manajer ingin bonus yang tinggi atas kerja yang telah dilakukan sementara pemilik perusahaan menginginkan return yang tinggi atas modal yang telah ditanamkan. Sebagai pihak yang melakukan operasional perusahaan, manajer mengetahui lebih banyak tentang kondisi perusahaan. Hal ini memungkinkan pihak manajer untuk mengungkapkan informasi yang tidak sesuai dengan kenyataan kepada pemilik. Perbedaan kepemilikan informasi inilah yang nantinya akan menimbulkan fenomena asimetri informasi.

Asimetri informasi ini menjadi celah yang dimanfaatkan manajer untuk melakukan manajemen laba. Manajer dapat menggunakan informasi lebih yang dimiliki untuk melakukan hal yang memaksimalkan bonus yang diterima. Berbeda dengan pemilik yang tidak dapat melakukan kontrol yang maksimal karena kurangnya informasi. Perbedaan kepentingan antara agen dan prinsipal ini menyebabkan kurang objektifnya keputusan yang diambil oleh pihak manajemen (Uwuigbe \& Olusanmi, 2011). Ketika keinginan atau tujuan kepala sekolah dan agen bertentangan, ini dapat menyebabkan masalah dalam hubungan. Masalah lain mungkin muncul ketika pelaku menghadapi kesulitan dalam memverifikasi apakah agen berperilaku sesuai dengan tujuan pelaku. Masalah ini masing-masing berkaitan dengan asumsi asimetri informasi dimana satu pihak memiliki akses unggul ke informasi, relatif terhadap pihak lain (Atikah, et al., 2018). Ketika perusahaan melakukan penghindaran pajak atau kegiatan perencanaan pajak, sebagai akibatnya mengurangi atau menunda kewajiban pajak, mengurangi upaya perubahan iklim perusahaan, sehingga lebih banyak uang dinikmati untuk disumbangkan, investasi, pengeluaran, dan tabungan (Pong, et al., 2014).

Laporan keuangan yang diterbitkan perusahaan menggunakan dua prinsip yang berbeda, yaitu prinsip akuntansi yang berlaku umum dan prinsip perpajakan (Putri, 2010). Manajer memiliki fleksibilitas dalam menyusun laporan keuangan karena adanya dua versi laporan keuangan yang berbeda ini. Laporan keuangan yang disusun sesuai prinsip akuntansi yang berlaku umum memberikan kesempatan manajer untuk menerapkan metode akuntansi yang beragam. Hal ini membuat manajer melakukan manipulasi laba dengan cara memperkecil laba perusahaan demi mengurangi beban pajak yang harus dibayar. Salah satu alasan yang dilakukan perusahaan melakukan manajemen 
laba adalah untuk mengurangi beban pajak yang tinggi (Kusumawardani \& Dewi, 2017).

Pajak merupakan beban yang cukup berat bagi perusahaan sehingga manajer melakukan banyak hal untuk meminimalkan pajak, salah satunya adalah dengan melakukan tax avoidance. Tax avoidance diartikan sebagai salah satu upaya menghindari pajak yang legal dan tidak melanggar peraturan (Inkiriwang, 2017). Namun nyatanya tindakan tax avoidance ini justru memberikan kerugian yang cukup besar kepada negara karena mengurangi penerimaan negara dari pajak.

Manajemen laba yang dilakukan manajer semata-mata digunakan untuk meningkatkan bonus yang diterima. Manajer melaporkan laba sesuai dengan yang diinginkan pemilik, sehingga bonus yang diterima pun meningkat. Indikator untuk menilai perilaku manajemen laba adalah discretionary accrual (DA). Terdapat tiga nilai yang perlu diperhatikan dalam discretionary accrual $(D A)$, manajemen laba yang dilakukan dengan meratakan laba (income smoothing) diperlihatkan dengan nilai nol, manajemen laba dengan meningkatkan laba (income increasing) ditunjukkan dengan nilai positif, dan manajemen laba dengan menurunkan laba (income decreasing) dinilai dengan nilai negatif (Ardika, 2015).

Manajer unit bisnis mungkin telah mencoba berbagai alasan melalui berbagai metode akuntansi, keuntungan finansial dukungan untuk mengubah kebijakan mereka. Manajer dapat menggunakan berbagai metode untuk memanipulasi laba, beberapa alat yang digunakan dalam kaitannya dengan manajemen laba, yang memiliki dampak langsung pada arus kas untuk memanipulasi akrual diskresioner termasuk, manajer juga termotivasi untuk mencapai margin laba yang diinginkan (Hassanpour \& Ardakani, 2017). Manajemen laba yang dilakukan dengan meningkatkan laba memiliki tujuan untuk meningkatkan bonus yang akan diterima oleh manajer. Sedangkan, manajamen laba dengan menurunkan laba bertuuan untuk menghindarkan perusahaan dari beban pajak yang besar. Laba yang tinggi dapat menyebabkan tingginya beban pajak, sehingga apabila perusahaan merasa pajak terlalu tinggi, maka manajer akan menurunkan labanya. Praktek manajemen laba memiliki efek penting pada profitabilitas dan kinerja perusahaan. Memeriksa hubungan antara manajemen laba dan kinerja sangat penting karena keuangan profitabilitas dan kinerja adalah sumber utama informasi bagi pengguna eksternal dan investor (Aldahab \& Own, 2017).

Salah satu cara yang dapat ditempuh untuk mencegah dan mengurangi praktik manajemen laba oleh manajer adalah dengan mengoptimalkan mekanisme good corporate governance (GCG). GCG memberikan jaminan kepada para pemangku kepentingan bahwa informasi perusahan yang diterbitkan bebas dari tindak kecurangan (Prastiti \& Meiranto, 2013). Mekanismen GCG memiliki dua fokus penting, yaitu terjaminnya hak pemilik untuk memperoleh informasi yang sebenarnya, dan kewajiban pihak manajemen untuk melaporkan informasi perusahaan seara cepat dan tepat (Ambarita \& Nuswantara, 2010). Pelaksanaan GCG sendiri berada di tangan dewan direksi perusahaan, untuk memastikan mekanisme tata kelola perusahaan berjalan baik dan sesuai aturan. Perusahaan di Indonesia memiliki dua badan kepengurusan yang memiliki tugas dan fungsi yang berbeda yakni dewan komisaris dan dewan direksi. 
Sistem tata kelola perusahaan yang dapat mencegah manajemen laba yang lain adalah struktur kepemilikan perusahaan yang terdiri atas kepemilikan manajerial, dan konstitusional. Kepemilikan manajerial menunjukkan bahwa saham perusahaan lebih banyak dimiliki oleh para manajer yang menjalankan operasi perusahaan. Manajer yang kini juga menjadi pemilik perusahaan lebih fokus pada tujuan bersama para pemilik lainnya sehingga keinginan untuk melakukan manajemen laba berkurang (Wiryadi \& Sebrina, 2013). Kepemilikan institusional didominasi oleh lembaga atau institusi yang menanamkan modalnya pada perusahaan. Perusahaan yang dimiliki lembaga umumnya memiliki kontrol yang lebih baik, karena lembaga akan mengontrol secara rutin kinerja dari manajer sehingga manajemen laba dapat dihindari. Pemberi modal yang berasal dari institusi biasanya melakukan proses pengawasan secara aktif karena mereka menginvestasikan dana yang tidak sedikit (Wiranata \& Nugrahanti, 2013).

Penelitian yang terdahulu memiliki perbedaan dalam hal hasil, seperti diantaranya penelitian oleh Iqball, (2010) menunjukkan bahwa dewan direksi memiliki pengaruh positif pada manajemen laba, berbanding terbalik dengan penelitian Oktaviani, (2014) yang justru menemukan hasil yang sebaliknya. Contoh lainnya adalah penelitian dari Sari, Halim, \& Fathoni, (2008) dan Lestari \& Putri, (2017) yang menunjukkan hasil berbeda, dimana Sari et al., (2008) memperoleh hasil bahwa dewan komisaris independen, kepemilikan manajerial, dan kepemilikan konstitusional berpengaruh positif pada manajemen laba, berbanding terbalik dengan penelitian (Lestari \& Putri, 2017). Perbedaan kepemilikan tersebut menarik peneliti untuk melakukan penelitian terkait hal ini pada perusahaan manufaktur yang didaftarkan dalam BEI.

Teori agensi dianggap sebagai teori permainan oleh Scott, (2018) yang memberikan gambaran untuk meluruskan perbedaan kepentingan dalam perusahaan. Kepentingan yang berbeda ini menimbulkan konflik yang cukup menghambat operasi perusahaan, karena manajer mungkin saja memanfaatkan kelebihan informasi yang dimiliki untuk mendahulukan kepentingannya di atas kepentingan pemilik. Teori agensi mencoba untuk memberikan gambaran mengenai hubungan antar kedua pemangku kepentingan ini.

Manusia memiliki keinginan alami untuk memperoleh keuntungan maksimal atas jerih payahnya, hal ini tidak terkecuali pada manajer yang menginginkan imbalan lebih besar atas kinerjanya dalam mengelola perusahaan. Di sisi lain, pemegang saham juga memiliki tujuan berbeda, yaitu untuk memperoleh pengembalian yang maksimal atas investasinya. Ini merupakan awal dari munculnya konflik kepentingan, dan mendorong manajemen untuk melaporkan hasil kinerja kemungkinan tidak sesuai dengan keadaan sesungguhnya. Manajer yang memiliki informasi lebih banyak memberikan peluang untuk melakukan manipulasi terhadap kinerja perusahaan yang tentunya sulit dideteksi pemilik karena pemilik memiliki informasi yang lebih minim. Dalam konsep teori keagenan, tindakan tax avoidance didorong oleh perbedaan kepentingan antara agen dan prinsipal untuk mencapai tujuannya masing-masing. 
Watts \& Zimmerman, (1990) memberikan tiga dasar untuk lebih mengerti terkait perilaku manajemen laba berdasarkan teori akuntansi positif, diantaranya pertama, The Bonus Plan Hypothesis memberikan bonus kepada manajer sesuai dengan tingkat laba yang diperoleh, dimana dalam hubungannya dengan tax avoidance, manajer akan berusaha melakukan minimalisasi pajak guna meningkatkan laba yang diperoleh; kedua, The Debt to Equity Hypothesis (Debt Covenant Hypothesis) menunjukkan perusahaan tidak mudah dalam memperoleh modal dari investor luar, hal ini membuat manajer perlu untuk menggunakan metode yang meningkatkan laba demi menghindari penerbitan surat utang, dimana penghindaran tersebut dapat dilakukan dengan efisiensi pajak; ketiga, The Political Cost Hypothesis (Size Hypothesis) yang mendorong manajer untuk memperkecil laba karena biaya politik perusahaan tinggi.

Manajemen laba diartikan sebagai pilihan manajer dalam menentukan metode yang digunakan dalam mengakui laba demi pencapaian tujuan (Scott, 2018). Manajemen laba merupakan perilaku yang diambil manajer dalam melaporkan kinerja keuangan perusahaan untuk mencapai tujuan pribadi (Prastiti \& Meiranto, 2013). Man \& Wong, (2013) mendefinisikan manajemen laba sebagai metode akuntansi yang digunakan untuk memanipulasi pendapatan sesuai target yang diinginkan. Dalam hubungan prinsipal-agen, agen yang pemegang saham mendelegasikan peran manajerial memiliki peluang besar untuk mengalihkan sebagian dari pendapatan potensial perusahaan kepada diri mereka sendiri (Siew Yee, et al., 2018).

Penghindaran pajak adalah penggunaan metode hukum untuk mengubah situasi keuangan menjadi lebih sedikit jumlahnya dari pajak penghasilan badan terhutang. Ini dicapai dengan mengklaim pengurangan dan kredit yang diizinkan (Thai Ha \& Quyen, 2017). Tax Avoidance oleh Lestari \& Putri, (2017) merupakan tindakan wajib pajak dalam mencari informasi mengenai metode untuk mengurangi kewajiban pajak secara legal. Tindakan semacam ini memberikan keuntungan kepada wajib pajak karena dapat mengurangi beban pajak yang seharusnya. Penghindaran pajak mencari informasi pada undangundang perpajakan yang tidak melanggar (Putra \& Ardiyanto, 2017). Penghindaran pajak dapat dilakukan dengan mencari kelemahan yang terdapat dalam peraturan pajak, seperti kurang jelasnya poin yang disebutkan dalam peraturan, sehingga dapat menimbulkan kesalahan tafsir. Namun, hal ini dapat memberikan citra buruk pada perusahaan apabila masyarakat mengetahui bahwa perusahaan melakukan tindakan penghindaran pajak. Tindakan tax avoidance jelas merugikan negara karena mengurangi pendapatan pajak, selain itu juga menyebabkan redistribusi pajak tidak maksimal antara perusahaan yang melakukan pembayaran pajak secara teratur dan perusahaan yang melakukan tax avoidance. Rendahnya rasio pajak pada tahun 2008 Indonesia disebabkan oleh kenyataan bahwa banyak wajib pajak di Indonesia melakukan penghindaran pajak. Penghindaran pajak dilakukan karena tarif pajak di Indonesia masih relatif tinggi dibandingkan dengan orang-orang dari negara lain di ASEAN (Rani, et al., 2018).

Tata kelola perusahaan (corporate governance) merupakan suatu mekanisme yang mengatur hubungan antar setiap fungsi yang terdapat dalam perusahaan, baik hubungan antar internal fungsi maupun eksternal fungsi demi mencapai 
kepentingan bersama. Tata kelola perusahaan sebagai salah satu alternatif dalam mencapai peningkatan kinerja perusahaan yang dilakukan dengan pengawasan secara rutin pada kinerja manajemen dan didasarkan pada aturan yang berlaku dalam perusahaan. Tata kelola perusahaan yang baik (Good Corporate Governance) diartikan sebagai konsep tata kelola perusahaan yang baik, yang memiliki 4 aspek penting, diantaranya keseimbangan antara fungsi-fungsi dewan komisaris, dewan direksi, dan RUPS, manajemen perusahaan yang bertanggungjawab pada pemangku kepentingan, hak-hak pemegang saham yang harus diakui, dan persamaan derajat antar pemegang saham.

Keberadaan komisaris independen dalam komposisi Dewan Komisaris dianggap memiliki pengaruh signifikan terhadap manajemen laba. Keberadaan komisaris independen diharapkan memainkan peran penting dalam memastikan penerapan praktik-praktik GCG yang baik sehingga mereka akan mengurangi praktik manajemen laba oleh seorang manajer (Laily, 2016). Tata Kelola Perusahaan yang baik adalah seperangkat aturan yang mengatur hubungan antara pemegang saham, wali (manajer), perusahaan, kreditor, pemerintah, karyawan, pemangku kepentingan dan internal dan eksternal lainnya yang terkait dengan hak dan kewajiban atau dengan kata lain, sistem yang mengontrol perusahaan (Tanjung, 2015).

Pentingnya GCG dalam penerapan pengelolaan perusahaan mendorong Komite Nasional Kebijakan Governance (KNKG) mengeluarkan lima asas yang harus dilaksanakan demi mencapai GCG, yaitu transparansi, akuntabilitas, responsibilitas, independensi, serta kewajaran dan kesetaraan. Keberhasilan perusahaan dan keberhasilan penerapan CG sangat dipengaruhi oleh interaksi antar organ perusahaan. Perusahaan memberikan tugas dan wewenang kepada masing-masing organ utama perusahaan yaitu RUPS, dewan komisaris, dan dewan direksi, serta kerjasama fungsi pendukung seperti sekretaris, komite, dan satuan pengawas internal (SPI).

Dewan direksi memiliki tanggung jawab dalam mengelola urusan perusahaan, termasuk hubungannya dengan pemasok, konsumen, dan pihak pembuat kebijakan. Dewan komisaris inependen merupakan perpanjangan dari pemegang saham minoritas dan bertugas dalam memberikan saran dan nasihat kepada dewan direksi, namun tidak memiliki hak dalam mengambil keputusan. Komite audit dan komisaris independen memastikan agar konflik kepentingan antar pemangku kepentingan dapat dihindari dalam perusahaan. Komite audit bersama dengan komisaris independen bertugas dalam melakukan pengawasan dalam pelaporan keuangan, dan manajemen perusahaan. Selain itu komite audit juga memiliki kewajiban dalam memastikan bahwa laporan keuangan yang dilaporkan kepada prinsipal adalah kredibel (Man \& Wong, 2013).

Kepemilikan institusional menjadi salah satu langkah dalam mengawasi kinerja manajer. Pemegang saham institusional dapat memberikan pengaruh manjemen terutama dalam penyusunan laporan keuangan (Prabaningrat, 2015). Setiap investor institusional, tidak peduli seberapa persentase kepemilikannya, tetap memiliki hak dalam memberikan pengawasan kepada manajemen (Mahadewi \& Krisnadewi, 2017). Kepemilikan manajerial memiliki pengaruh yang sama dalam mengurangi tindak manajemen laba yang tidak benar. Manajer akan secara cermat dalam mengambil keputusan terkait laba karena setiap 
keputusan yang diambil akan berpengaruh pada modal yang telah diinvestasikan. Investor institusi, relatif terhadap investor individu, memiliki lebih banyak kemampuan untuk mengumpulkan, menginterpretasikan laporan keuangan dan mendeteksi oportunisme manajerial atas angka pendapatan (Farouk \& Bashir, 2017). Kemampuan eksekutif untuk secara miopik terlibat dalam kegiatan manajemen laba sangat dipengaruhi oleh efektivitas pemantauan yang dilakukan oleh investor institusi (Lemma, et al., 2018).

Beban pajak yang ditanggung perusahaan dipengaruhi oleh besarnya pajak yang dilaporkan. Perusahaan dengan penghasilan yang tinggi tentu akan dibebani pajak yang semakin tinggi. Hal inilah yang menjadi faktor dilakukannya praktik manajemen laba. Penghindaran pajak menjadi salah satu cara yang dapat dilakukan pihak manajer untuk meningkatkan laba. Penelitian yang mendukung pernyataan tersebut diantaranya (Lestari \& Putri, 2017). Penghindaran pajak dapat mempengaruhi manajemen laba sebab peratuan pajak dan metode akuntansi untuk mengakui laba memiliki beberapa perbedaan yang dapat dijadikan peluang bagi manajemen untuk melakukan manipulasi laba. Penelitian oleh Harmana \& Suardana, (2014) memberikan petunjuk bahwa pajak yang direncanakan dapat berguna dalam mengetahui kemungkinan tindakan manajemen laba. Teori akuntansi positif memberikan gambaran mengenai biaya politik yang tinggi dapat mendorong manajer melaporkan laba yang lebih kecil. Maka hipotesis pertama sebagai berikut.

$\mathrm{H}_{1}$ : Tax avoidance berpengaruh positif pada manajemen laba.

Teori agensi menyatakan adanya hubungan antara manajer dengan pemilik perusahaan yang masing-masing memiliki kepentingan. Selanjutnya, twori akuntansi positif memberikan penjelasan bahwa manajer memiliki sifat rasional untuk bertindak demi kepentingannya sendiri. Abbadi, et al., (2016) berpendapat bahwa manajer dapat menggunakan metode yang meningkatkan laba agar kinerja buruk perusahaan tidak terlihat oleh pihak lain. Dewan direksi memiliki kewajiban dalam melakukan tata kelola perusahaan, hal ini memberikan tanggungjawab besar perusahaan kepada direksi. Perusahaan yang mengalami kesulitan dalam mencapai target yang ditetapkan investor bukanlah hal yang baik. Untuk itu, manajemen akan melakukan manajemen laba untuk memastikan perusahaan mencapai target yang ditetapkan. Selain itu, kebijakan bonus yang diterapkan perusahaan juga menjadi pendorong manajer melakukan manipulasi laba demi memperoleh bonus yang lebih tinggi. Penjelasan tersebut membawa kita pada rumusan hipotesis kedua berikut.

$\mathrm{H}_{2}$ : Dewan direksi berpengaruh positif pada manajemen laba.

Dewan komisaris independen yang memiliki tugas dalam melakukan pengawasan terhadap jalannya perusahaan dapat menjadi salah satu cara untuk mengurangi tindakan manajemen laba. Jensen \& Meckling, (1976) menyatakan bahwa dalam teori agensi dewan komisaris memiliki peran penting daam mengontrol tindakan dewan direksi yang berkaitan dengan sifat oportunistik direksi. Penelitian Dananjaya \& Ardiana, (2016) semakin menegaskan bahwa adanya dewan komisaris independen dapat mencegah terjadinya manajemen laba. Berdasarkan uraian tersebut, hipotesis ketiga adalah. 
$\mathrm{H}_{3}$ : Dewan komisaris independen berpengaruh negatif pada manajemen laba.

Komite audit merupakan pihak independen yang memiliki tugas untuk melakukan pengawasan laporan keuangan perusahaan dan memperbaiki apabila terdapat kesalahan. Komite audit dapat menghambat manajemen laba karena komite audit merupakan pihak yang tidak memiliki kepentingan apapun terhadap perusahaan, sehingga laporannya tentu akan objektif. Pentingnya keberadaan komite audit membuat fungsi ini diatur dalam peraturan pemerintah yang mengharuskan perusahaan untuk memiliki komite audit. Rumusan hipotesis keempat dalam penelitian ini yaitu.

$\mathrm{H}_{4}$ : Komite audit berpengaruh negatif pada manajemen laba.

Kepemilikan institusional merupakan kepemilikan perusahaan oleh institusi atau lembaga tertentu yang memiliki kontrol yang kuat. Institusi yang memiliki sebuah perusahaan tentu akan memberikan pengawasan yang maksimal terhadap manajer yang melakukan pengelolaan. Kodriyah, (2015) dalam pendapatnya menyatakan bahwa investor institusional memiliki pengaruh besar dalam perusahaan sesuai dengan persentase kepemilikannya yang juga besar. Mahadewi \& Krisnadewi, (2017) dalam penelitiannya menemukan bahwa manajemen laba dapat dihindari melalui pengawasan rutin dari pemegang saham institusional. Uraian tersebut mengembangkan hipotesis seperti berikut.

$\mathrm{H}_{5}$ : Kepemilikan institusional berpengaruh negatif pada manajemen laba.

Perusahaan yang sahamnya mayoritas dimiliki oleh manajemen mampu mengurangi tindak manajemen laba, karena segala keputusan akuntansi yang diambil akan berpengaruh pada return yang kemungkinan diperoleh manajer. Manajer akan lebih cermat dan berhati-hati terlebih dalam memutuskan tindakan manipulasi laba karena mereka tidak hanya bertindak sebagai pengelola perusahaan namun juga sebagai pemilik. Hal ini menyebabkan hasil penelitian dengan hubungan negatif antara kepemilikan manajerial dan praktik manajemen laba oleh (Nugroho \& Darsono, 2015). Berdasarkan uraian di atas, maka hipotesis keenam dalam penelitian ini adalah.

$\mathrm{H}_{6}$ : Kepemilikan manajerial berpengaruh negatif pada manajemen laba.

\section{METODE PENELITIAN}

Penelitian ini bertujuan memperoleh hubungan yang timbul antar variabel bebas terhadap variabel terikat. Uji statistic deskriptif yang dilakukan yaitu Uji asumsi klasik yang dilakukan yaitu, uji normalitas, uji autokorelasi, uji multikolinealitas, dan uji heterokedasitas, Analisis Regresi Linear Berganda Koefisien Determinasi $\left(\mathrm{R}^{2}\right)$ Uji Model (Uji F) Uji Hipotesis (Uji t). Model penelitian dapat dilihat pada Gambar 1. 


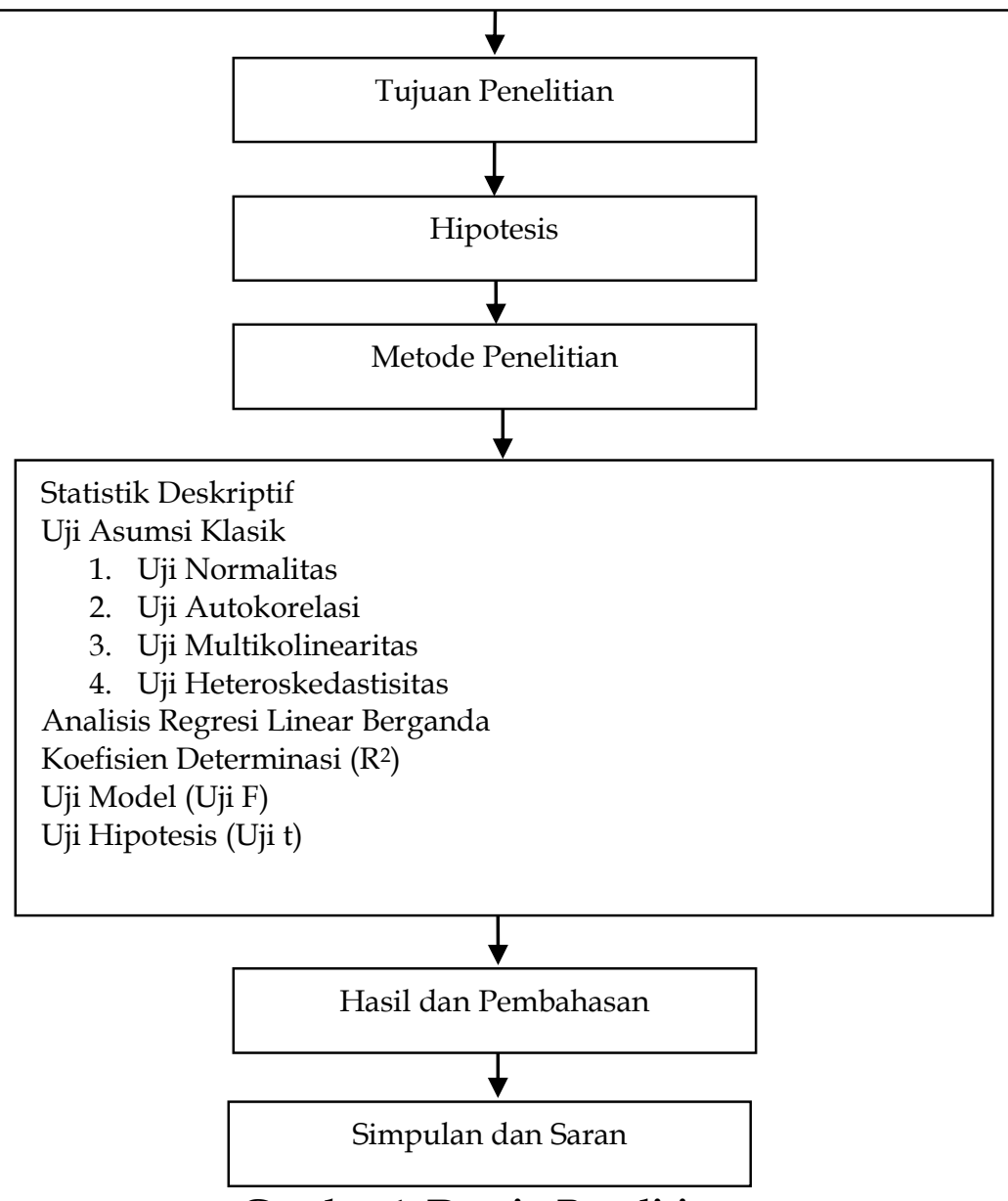

Sumber: Data Penelitian, 2019

Gambar 1. Desain Penelitian

Penelitian dilakukan di BEI, dengan mengakses web resmi BEI terkait perusahaan manufaktur periode 2013-2017._Penelitian ini berpedoman pada model Jones (1991) untuk menghitung discretionary accruals dengan langkah berikut. Pertama, nilai total accruals ditentukan dengan mengkategorikan antara discretionary accruals dengan non-discretionary accrual dengan rumus berikut.

$\mathrm{TA}=\mathrm{NDA}+\mathrm{DA}$

lakukan penghitungan total accruals berikut.

$\mathrm{TA}=\mathrm{NI}-\mathrm{CFO}$

Nilai non-discretionary accrual kemudian dihitung melalui cara berikut.

$N A_{i t}=a_{1}\left(1 / A_{i t-1}\right)+a_{2}\left(\Delta \operatorname{Rev}_{t} / A_{i t-1}-\Delta \operatorname{Rec}_{t} / A_{i t-1}\right)+a_{3}\left(P P E_{t} / A_{i t-1}\right)$

Parameter dalam persamaan (3) diperoleh dari hasil regresi yang menggunakan model Jones (1991), yaitu:

$\mathrm{TA}_{\mathrm{it}}-/ \mathrm{A}_{\mathrm{it}-1}=\mathrm{a}_{1}\left(1 / \mathrm{A}_{\mathrm{it}-1}\right)+\mathrm{a}_{2}\left(\Delta \operatorname{Rev}_{\mathrm{t}} / \mathrm{A}_{\mathrm{it}-1}\right)+\mathrm{a}_{3}\left(\mathrm{PPE}_{\mathrm{t}} / \mathrm{A}_{\mathrm{it}-1}\right)+\varepsilon$

Dalam persamaan (4) terlihat bahwa nilai discretionary accruals merupakan nilai residu (error term) dari regresi, dan untuk menghitung nilai discretionary accruals dilakukan dengan rumus:

$\mathrm{DA}_{\mathrm{it}}=\mathrm{TA}_{\mathrm{it}}-/ \mathrm{A}_{\mathrm{it}-1}-\left[\mathrm{a}_{1}\left(1 / \mathrm{A}_{\mathrm{it}-1}\right)+\mathrm{a}_{2}\left(\Delta \operatorname{Rev}_{\mathrm{t}} / \mathrm{A}_{\mathrm{it}-1}-\Delta \operatorname{Rec}_{\mathrm{t}} / \mathrm{A}_{\mathrm{it}-1}\right)+\mathrm{a}_{3}\left(\mathrm{PPEt} / \mathrm{A}_{\mathrm{it}-1}\right] \ldots\right.$ 
Dimana:

TA : Total accruals dalam periode $t$

NDA : Non-discretionary accruals dalam periode $t$

DA : Discretionary accruals dalam periode $\mathrm{t}$

A $\quad$ : Total assets periode $\mathrm{t}-1$

$\Delta \operatorname{Rev} \quad:$ Perubahan penjualan bersih dalam periode $t$

$\Delta$ Rec $\quad$ : Perubahan piutang bersih dalam periode $t$

PPE : Property, Plan and Equipment dalam periode $t$

$\mathrm{a}_{1}, \mathrm{a}_{2}, \mathrm{a}_{3}$ : Parameter yang diperoleh dari regresi persamaan (4)

Penelitian ini mengambil seluruh perusahaan manufaktur pada periode 2013-2017 yang terdaftar di BEI sebagai populasi, yaitu sebanyak 131 perusahaan. Sedangkan sampel penelitian ditentukan dengan metode purposive sampling, dimana kriterianya adalah perusahaan manufaktur di BEI pada 20132017, mengeluarkan laporan keuangan pada akhir periode 31 Desember, laporan keuangan yang dikeluarkan perusahaan haruslah menggunakan mata uang rupiah, dan perusahaan dalam periode tersebut tidak mengalami kerugian.

Pengumpulan data dilakukan oleh peneliti dengan metode observasi non partisipan, yang tida terlibat langsung dalam pengamatan. Teknik analisis data menggunakan analisis regresi linear berganda dengan rumus sebagai berikut.

$$
Y=\alpha+\beta_{1} X_{1}+\beta_{2} X_{2}+\beta_{3} X_{3}+\beta_{4} X_{4}+\beta_{5} X_{5}+\beta_{6} X_{6}+e
$$

\section{HASIL DAN PEMBAHASAN}

Perusahaan manufaktur sebagai populasi dalam penelitian berjumlah 131 perusahaan. Setelah diseleksi sesuai kriteria purposive sampling ditunjukkan pada tabel 1.

Tabel 1. Seleksi Pemilihan Sampel

\begin{tabular}{|c|c|c|}
\hline No & Kriteria & Jumlah \\
\hline 1 & $\begin{array}{l}\text { Perusahaan manufaktur yang terdaftar di } \text { Bursa } \\
\text { Indonesia tahun 2013-2017 }\end{array}$ & 131 \\
\hline 2 & $\begin{array}{l}\text { Perusahaan manufaktur yang tidak terdaftar di Bursa Efek } \\
\text { Indonesi (BEI) secara berturut-turut pada periode pengamatan } \\
\text { 2013-2017. }\end{array}$ & (49) \\
\hline 3 & $\begin{array}{l}\text { Perusahaan yang tidak menerbitkan laporan keuangan akhir } \\
\text { periode } 31 \text { Desember. }\end{array}$ & (10) \\
\hline 4 & $\begin{array}{l}\text { Perusahaan yang tidak menampilkan laporan keuangan } \\
\text { dalam mata uang rupiah agar laporan keuangan yang } \\
\text { digunakan memiliki keseragaman mata uang saat perhitungan }\end{array}$ & (10) \\
\hline 5 & $\begin{array}{l}\text { Perusahaan yang tidak mengalami kerugian pada periode } \\
\text { pengamatan 2013-2017 }\end{array}$ & $(50)$ \\
\hline \multicolumn{2}{|c|}{ Jumlah sampel penelitian } & 12 \\
\hline \multicolumn{2}{|c|}{ Tahun pengamatan } & 5 \\
\hline \multicolumn{2}{|c|}{ Jumlah data selama periode penelitian } & 60 \\
\hline
\end{tabular}

Sumber : Data Penelitian, 2018

Sesuai tabel 1, maka hanya 12 perusahaan per tahun yang memenuhi kriteria dalam pemilihan sampel penelitian, sehingga jumlah perusahaan dalam 5 tahun berturut-turut adalah sebesar 60 perusahaan. 
Statistik deskriptif memberikan informasi terkait data/variabel yang diteliti dalam sebuah penelitian. Lebih lanjut hasil statistik deskriptif dapat dilihat pada tabel 2.

\section{Tabel 2. Hasil Uji Statistik Deskriptif}

\begin{tabular}{lccccc}
\hline & $\mathrm{N}$ & Minimum & Maximum & Mean & $\begin{array}{c}\text { Std. } \\
\text { Deviation }\end{array}$ \\
\hline Tax avoidance & 60 & 0,018 & 1,38 & 0,28 & 0,221 \\
Jumlah dewan direksi & 60 & 3 & 11 & 5,58 & 2,59 \\
Dewan komisaris & 60 & 0,3 & 0,5 & 0,38 & 0,065 \\
independen & & & & & \\
Komite audit & 60 & 0,33 & 1 & 0,76 & 0,18 \\
Kepemilikan institusional & 60 & 0 & 0,96 & 0,24 & 0,37 \\
Kepemilikan manajerial & 60 & 0 & 0,67 & 0,083 & 0,018 \\
Manajemen laba & 60 & $-0,18$ & 0,22 & 0,015 & 0,009 \\
Valid N (listwise) & 60 & & & & \\
\hline
\end{tabular}

Sumber : Data Penelitian, 2018

Variabel tax avoidance $\left(\mathrm{X}_{1}\right)$ memiliki nilai terendah (minimum) sebesar 0,018 dan nilai tertinggi (maximum) sebesar 1,38. Sementara standar deviasinya sebesar 0,221 dan nilai rata-ratanya (mean) yaitu sebesar 0,28. Variabel jumlah dewan direksi $\left(\mathrm{X}_{2}\right)$ mempunyai nilai terendah (minimum) 3 dan nilai tertinggi (maximum) 11. Sedangkan, standar deviasinya sebesar 2,59 dan nilai rata-rata (mean) yaitu sebesar 5,58.

Variabel dewan komisaris independen $\left(X_{3}\right)$ mempunyai nilai terendah (minimum) 0,3 dan nilai tertinggi (maximum) 0,5. Sedangkan, standar deviasi sebesar 0,065 dan nilai rata-ratanya (mean) yaitu sebesar 0,38. Variabel komite audit $\left(\mathrm{X}_{4}\right)$ mempunyai nilai terendah (minimum) 0,33 dan nilai tertinggi (maximum) 1. Sedangkan, standar deviasi sebesar 0,18 dan nilai rata-ratanya (mean) yaitu sebesar 0,76.

Variabel persentase kepemilikan institusional $\left(X_{5}\right)$ mempunyai nilai terendah (minimum) 0 dan nilai tertinggi (maximum) 0,96 (96\%). Sedangkan, standar deviasi sebesar 0,37 (37\%) dan nilai rata-ratanya (mean) yaitu sebesar 0,24 $(24 \%)$. Variabel persentase kepemilikan manajerial $\left(\mathrm{X}_{6}\right)$ mempunyai nilai terendah (minimum) 0 dan nilai tertinggi (maximum) 0,67 (67\%). Sedangkan, standar deviasi sebesar $0,018(1,8 \%)$ dan nilai rata-ratanya (mean) yaitu sebesar $0,083(8,3 \%)$. Variabel manajemen laba $(\mathrm{Y})$ mempunyai nilai terendah (minimum) $-0,18$ dan nilai tertinggi (maximum) 0,22. Sedangkan, standar deviasi sebesar 0,009 dan nilai rata-ratanya (mean) yaitu sebesar 0,015.

Uji normalitas merupakan salah satu syarat regresi linear berganda untuk menilai distribusi residual data, dimana setiap model penelitian yang baik diharapkan untuk memperoleh data yang berdistribusi normal yang dibuktikan dengan nilai Asymp. Sig. (2-tailed) berada di atas 0,05. 
Tabel 3. Hasil Uji Normalitas

\begin{tabular}{llr}
\hline & & Unstandardized Residual \\
\hline $\mathrm{N}$ & & 60 \\
Normal Parameters ${ }^{a, b}$ & Mean & 0,000 \\
& Std. Deviation & 0,085 \\
Most Extreme Differences & Absolute & 0,095 \\
& Positive & 0,095 \\
& Negative & $-0,066$ \\
Kolmogorov-Smirnov Z & & 0,732 \\
Asymp. Sig. (2-tailed) & & 0,657 \\
\hline
\end{tabular}

Sumber: Data Penelitian, 2018

Hasil pada tabel 3 menunjukkan bahwa nilai Asymp. Sig. (2-tailed) sebesar 0,657 berada di atas 0,05 sehingga data berdistribusi normal, dan model dapat diterima untuk tahap analisis selanjutnya.

Uji autokorelasi digunakan untuk menjelaskan ketentuan daerah terjadinya autokorelasi positif atau negatif, maupun tidak terjadi autokorelasi. Model regresi tidak terdapat autokorelasi apabila nilai Durbin-Watson lebih besar dari batas (du) dan kurang dari 4-du seperti berikut.

Tabel 4. Hasil Uji Durbin-Watson

\begin{tabular}{lrrrrr}
\hline Model & $R$ & $R$ Square & $\begin{array}{c}\text { Adjusted } R \\
\text { Square }\end{array}$ & $\begin{array}{c}\text { Std. Error of the } \\
\text { Estimate }\end{array}$ & Durbin-Watson \\
\hline 1 &, $835^{\mathrm{a}}$ &, 697 &, 589 &, 0897472 & 1,965 \\
\hline
\end{tabular}

Sumber : Data Penelitian, 2018

Hasil uji Durbin Watson padal tabel 4 dalam penelitian ini diketahui bahwa nilai DW sebesar 1,965 yang berarti nilai DW berada diantara dU $(1,808)$ dan 4dU (2,192); $(1,808<1,965<2,192)$ maka dapat disimpulkan bahwa tidak terjadi autokorelasi dalam model regresi penelitian ini.

Uji multikoliniearitas dilakukan untuk menentukan korelasi antar variabel bebas, dimana dalam uji ini diharapkan agar model penelitian terbebas dari multikolinearitas. Berikut hasil uji multikoliniearitas pada tabel 5.

\section{Tabel 5. Hasil Uji Multikolinieritas}

\begin{tabular}{lllrl}
\hline No & \multicolumn{1}{c}{ Variabel Bebas } & Tolerance & VIF & Keterangan \\
\hline 1 & Tax avoidance & 0,974 & 1,027 & Bebas Multikolinieritas \\
2 & Jumlah dewan direksi & 0,814 & 1,229 & Bebas Multikolinieritas \\
& Dewan komisaris & 0,738 & 1,354 & \\
3 & independen & & & Bebas Multikolinieritas \\
4 & Komite audit & 0,608 & 1,644 & Bebas Multikolinieritas \\
5 & Kepemilikan institusional & 0,817 & 1,224 & Bebas Multikolinieritas \\
6 & Kepemilikan manajerial & 0,799 & 1,251 & Bebas Multikolinieritas \\
\hline
\end{tabular}

Sumber: Data Penelitian, 2018

Penelitian ini tidak mengandung multikoliniearitas, yang dapat dilihat dari nilai tolerance dan VIF dari masing-masing variabel bebas yang lebih dari 0,1 dan kurang dari 10.

Model regresi yang dapat digunakan adalah model yang tidak mengandung heteroskedastisitas antar variabel bebas yang dilakukan dengan uji 
glejser. Apabila nilai signifikansi di atas 0,05 maka variabel tidak mengandung heteroskedastisitas. Berikut hasil uji heteroskeastisitas pada tabel 6 .

Tabel 6. Hasil Uji Heteroskedastisitas

\begin{tabular}{|c|c|c|c|c|c|}
\hline \multirow[b]{2}{*}{ Model } & \multicolumn{2}{|c|}{$\begin{array}{l}\text { Unstandardized } \\
\text { Coefficients }\end{array}$} & \multirow{2}{*}{$\begin{array}{c}\text { Standardized } \\
\text { Coefficients } \\
\text { Beta } \\
\end{array}$} & \multirow[b]{2}{*}{$\mathrm{t}$} & \multirow[b]{2}{*}{ Sig. } \\
\hline & $\mathrm{B}$ & Std. Error & & & \\
\hline 1 (Constant) & 0,105 & 0,071 & & 1,472 & 0,147 \\
\hline Tax avoidance & 0,054 & 0,028 & 0,231 & 1,924 & 0,060 \\
\hline Jumlah dewan direksi & $-0,006$ & 0,003 & $-0,281$ & $-2,141$ & 0,069 \\
\hline $\begin{array}{l}\text { Dewan komisaris } \\
\text { independen }\end{array}$ & $-0,072$ & 0,109 & $-0,091$ & $-0,662$ & 0,511 \\
\hline Komite audit & $-0,002$ & 0,045 & $-0,007$ & $-0,044$ & 0,965 \\
\hline Kepemilikan institusional & 0,049 & 0,018 & 0,352 & 2,684 & 0,101 \\
\hline Kepemilikan manajerial & $-0,059$ & 0,038 & $-0,209$ & $-1,579$ & 0,120 \\
\hline
\end{tabular}

Sumber: Data Penelitian, 2018

Hasil uji heterokedastisitas dengan menggunakan uji glejser menunjukkan bahwa keenam variabel bebas yang meliputi tax avoidance $\left(\mathrm{X}_{1}\right)$, dewan direksi $\left(X_{2}\right)$, dewan komisaris independen $\left(X_{3}\right)$, komite audit $\left(X_{4}\right)$, persentase kepemilikan institusional $\left(X_{5}\right)$ dan persentase kepemilikan manajerial $\left(X_{6}\right)$ memiliki nilai signifikansi di atas 0,05 sehingga dapat disimpulkan bahwa data tersebut tidak mengalami heteroskedastisitas.

Analisis regresi linear dilakukan untuk menguji apakah terdapat pengaruh variabel bebas terhadap variabel terikat, dan bagaimana pengaruh yang ditimbulkan tersebut. Hasil regresi linear berganda ditunjukkan pada tabel 7.

Tabel 7. Persamaan Regresi Linier Berganda

\begin{tabular}{|c|c|c|c|c|c|c|c|}
\hline \multirow[b]{2}{*}{ Model } & \multirow{2}{*}{\multicolumn{3}{|c|}{$\begin{array}{c}\text { Standardize } \\
d \\
\text { Coefficients } \\
\text { Beta }\end{array}$}} & \multirow[b]{2}{*}{$\mathrm{T}$} & \multirow[b]{2}{*}{ Sig. } & \multicolumn{2}{|c|}{$\begin{array}{c}\text { Collinearity } \\
\text { Statistics }\end{array}$} \\
\hline & & & & & & Tolerance & VIF \\
\hline 1 (Constant) & $-0,116$ & 0,136 & & $-0,856$ & 0,396 & & \\
\hline Tax avoidance & 0,037 & 0,054 & 0,091 & 4,681 & 0,005 & 0,974 & 1,027 \\
\hline $\begin{array}{l}\text { Jumlah dewan } \\
\text { direksi }\end{array}$ & 0,001 & 0,005 & 0,026 & 4,178 & 0,009 & 0,814 & 1,229 \\
\hline $\begin{array}{l}\text { Dewan komisaris } \\
\text { independen }\end{array}$ & $-0,029$ & 0,208 & $-0,021$ & $-4,139$ & 0,009 & 0,738 & 1,354 \\
\hline Komite audit & $-0,130$ & 0,085 & $-0,260$ & $-5,533$ & 0,001 & 0,608 & 1,644 \\
\hline $\begin{array}{l}\text { Kepemilikan } \\
\text { institusional }\end{array}$ & $-0,032$ & 0,035 & $-0,135$ & $-4,920$ & 0,004 & 0,817 & 1,224 \\
\hline $\begin{array}{l}\text { Kepemilikan } \\
\text { manajerial }\end{array}$ & $-0,021$ & 0,071 & $-0,044$ & $-4,297$ & 0,008 & 0,799 & 1,251 \\
\hline
\end{tabular}

Sumber: Data Penelitian, 2018

Berdasarkan tabel 7 tersebut, didapat nilai pada rumus regresi berikut. $\mathrm{Y}=-0,116+0,037 \mathrm{X}_{1}+0,001 \mathrm{X}_{2}-0,029 \mathrm{X}_{3}-0,130 \mathrm{X}_{4}-0,032 \mathrm{X}_{5}-0,021 \mathrm{X}_{6}+\mathrm{e}$

Nilai -0,116 memperlihatkan apabila nilai variabel bebas dianggap nol, maka variabel manajemen laba turun sebesar 0,116. Nilai variabel X1 sebesar 0,037 menunjukkan apabila variabel tax avoidance naik sebesar 1 satuan maka manajemen laba akan naik 0,037 satuan, begitupula unutk variabel dewa direksi. 
Sedangkan, apabila variabel dewa komisaris naik sebesar 1 satuan, maka manajemen laba akan turun sebesar 0,029 satuan, sama halnya dengan variabel komite audit, kepemilikian institusional, dan kepemilikan manajerial.

Dapat dilihat bahwa nilai adjusted R Square sebesar 0,589 (58,9\%). Hal ini berarti $58,9 \%$ variasi manajemen laba dapat dijelaskan oleh variabel tax avoidance $\left(X_{1}\right)$, dewan direksi $\left(X_{2}\right)$, dewan komisaris independen $\left(X_{3}\right)$, komite audit $\left(X_{4}\right)$, persentase kepemilikan institusional $\left(\mathrm{X}_{5}\right)$ dan persentase kepemilikan manajerial $\left(\mathrm{X}_{6}\right)$. Sisanya $47,4 \%$ dijelaskan oleh faktor lain yang tidak disertakan dalam variabel penelitian ini.

Uji F dilakukan untuk menentukan apakah model layak untuk digunakan dalam penelitian, dengan melihat nilai signifikansi $\mathrm{F}$ yang harus kurang dari 0,05. Berikut tabel uji F pada tabel 8.

Tabel 8. Hasil Uji Kelayakan Model (Uji F)

\begin{tabular}{|c|c|c|c|c|c|c|}
\hline \multicolumn{2}{|c|}{ Model } & Sum of Squares & \multirow[t]{2}{*}{$D f$} & Mean Square & \multirow{2}{*}{$\begin{array}{l}F \\
4,659\end{array}$} & \multirow{2}{*}{$\frac{\text { Sig. }}{0,007^{a}}$} \\
\hline 1 & Regression & 0,032 & & 0,005 & & \\
\hline & Residual & 0,427 & 53 & 0,008 & & \\
\hline & Total & 0,459 & 59 & & & \\
\hline
\end{tabular}

Sumber: Data Penelitian, 2018

Tabel 8 menunjukkan bahwa nilai signifikansi 0,007 kurang dari 0,05 sehingga model layak digunakan, dan memperlihatkan adanya pengaruh variabel bebas terhadap variabel terikat secara simultan.

Nilai signifikansi variabel tax avoidance menunjukkan 0,005 kurang dari 0,05 sehingga $\mathrm{H} 1$ diterima, yaitu tax avoidance berpengaruh positif pada manajemen laba. Pembayaran pajak yang tinggi maupun rendah akan memberikan sinyal kepada pihak manajemen untuk melakukan langkah-langkah strategis dalam mengurangi beban pajak yang diterima, salah satunya adalah dengan melakukan manajemen laba.

Teori akuntansi positif dalam kaitannya dengan biaya politik menyatakan bahwa laba yang tinggi akan membuat semakin tingginya biaya politik yang dibebankan pada perusahaan. Hal ini memaksa manajemen untuk melakukan manajemen laba demi menurunkan biaya politik perusahaan, sehingga target dari pihak prinsipal dapat tercapai. Hasil ini sejalan dengan hasil penelitian Larastomo, et al., (2016) tekait pengaruh positif yang diberikan tax avoidance kepada manajemen laba.

Variabel dewan direksi memiliki nilai signifikansi 0,009 kurang dari 0,05 sehingga hipotesis kedua diterima, yaitu dewan direksi memberikan pengaruh positif pada manajemen laba. Dewan direksi sebagai pengelola perusahaan akan terdorong untuk melakukan manajemen laba demi memperoleh bonus dan keuntungan lainnya.

Teori agensi menyatakan bahwa akan selalu ada perbedaan tujuan antara manajer dengan pemilik. Perbedaan ini disebabkan karena adanya persentasi kepemilikan informasi yang berbeda antara kedua pihak tersebut. Teori akuntansi positif terkait bonus memberikan penjelasan bahwa manajer akan tertarik oleh bonus yang diberikan perusahaan apabila target telah tercapai. Oleh karena itu, dewan direksi akan melakukan manajemen laba demi mencapat bonus tersebut. 
Sama halnya dengan dewan direksi, dewan komisaris independen memiliki nilai signifikansi sebesar 0.009 yang kurang dari 0,05 sehingga dewan komisaris independen berpengaruh negatif dengan manajemen laba sesuai rumusan hipotesis ketiga. Dewan komisaris yang bertanggungjawab dalam mengawasi jalannya perusahaan dan kinerja dewan direksi dapat menjadi penghambat manajer melakukan manajemen laba. Komposisi yang tepat dalam dewan komisaris akan mengefektifkan fungsi pengawasan.

Dalam teori agensi, komisaris independen berpengaruh dalam mengawasi tindakan manajer yang memiliki sifat oportunistik. Penelitian ini sejalan dengan penelitian Taco \& Ilat, (2016) terkait pengaruh negatif komisaris independen pada praktik manajemen laba.

Variabel komite audit memiliki nilai signifikan sebesar 0,001 kurang dari 0,05 sehingga hipotesis keempat diterima, yaitu komite audit berpengaruh negatif pada manajemen laba. Sama halnya dengan komisaris independen, komite audit juga memiliki tugas dalam memberikan kontrol dan pengawasan terhadap kinerja manajer terutama dalam hal pelaporan keuangan dan manajemen risiko.

Komite audit selain mengawasi juga dapat memperbaiki apabila laporan keuangan memiliki beberapa kekelirua. Inilah yang menyebabkan bahwa komite audit dapat mengurangi kemungkinan manajemen laba, karena laporan keuangan akan dievaluasi terlebih dahulu terkait kebenaran dan kelayakannya sebelum diberikan informasinya kepada pemilik saham.

Kepemilikan institusional berpengaruh negatif pada manajemen laba sesuai nilai signifikansi 0,004 yang berada di bawah 0,05. Kepemilikan perusahaan yang didominasi oleh lembaga atau institusi memiliki mekanisme pengawasan yang lebih tinggi, karena pemilik akan memberikan pengawasan secara rutin dan teratur terkait kinerja manajer. Manajer tentu akan merasa terbebani dan takut untuk melakukan tindakan yang dapat mengancam keberadaannya dalam perusahaan sehingga manajemen laba dapat dihindari.

Sesuai dengan hipotesis yang diajukan bahwa kepemilikan manajerial berpengaruh negatif pada manajemen dari hasil uji $t$ menunjukkan nilai signifikansi kepemilikan manajerial yaitu 0,008 yang mana nilai tersebut $<0,05$ yang berarti kepemilikan manajerial berpengaruh negatif pada manajemen laba. Meskipun dalam teori akuntansi disebutkan bahwa manajer termotivasi untuk melakukan manajemen laba demi memperoleh bonus, namun apabila manajer menjadi pemilik saham mayoritas, maka manajer akan berpikir ulang dalam melakukan tindakan yang merugikan perusahaan. Hal ini akan berpengaruh pada berkurangnya tindakan manajemen laba yang mungkin akan dilakukan. Penelitian ini sebanding dengan Nugroho \& Darsono, (2015) bahwa kepemilikan manajerial memberikan pengaruh negatif pada manajemen laba.

\section{SIMPULAN}

Manajemen laba merupakan salah satu tindakan yang dilakukan manajer demi mencapai tujuan-tujuan tertentu, seperti tercapainya target dari pemilik perusahaan atau diperolehnya bonus yang menguntungkan manajer. Praktik manajemen laba ternyata dipengaruhi secara positif oleh tax avoidance, dan dewan direksi. Tax avoidance dilakukan agar perusahaan tidak terbebani dalam 
membayar pajak sehingga dibuatlah laba yang kecil, sedangkan dewan direksi demi memperoleh bonus maka akan melakukan manajemen laba. Sedangkan mekanisme GCG yang terdiri dari dewan komisaris, komite audit, kepemilikan institusional dan kepemilikan manajerial berpengaruh negatif pada manajemen laba.

\section{REFERENSI}

Abbadi, S., Hijazi, Q., \& Al-Rahahleh, A. (2016). Corporate Governance Quality and Earnings Management: Evidence from Jordan. Australasian Accounting, Business and Finance Journal, 10(2), 54-75. https:// doi.org/10.14453/aabfj.v10i2.4

Ambarita, E., \& Nuswantara, D. A. (2010). Pengaruh Penerapan Mekanisme Good Corporate Governance terhadap Praktik Manajamen Laba pada Perusahaan Manufaktur yang Terdaftar di Bursa Efek Indonesia. Jurnal Akuntansi Akrual, 1(1), 28-44.

Ardika, G. (2015). Praktik Manajemen Laba Sebelum dan Sesudah Initial Public Offering. Universitas Lampung.

Atikah, N., Shafai, B., Bin, A., \& Ganesan, Y. (2018). Earnings Management, Tax Avoidance and Corporate Social Responsibility: Malaysia Evidence. International Academic Journal of Accounting and Financial Management, 5(3), 41-56.

Dananjaya, D. G. yudha, \& Ardiana, P. A. (2016). Proporsi Dewan Komisaris Independen sebagai Pemoderasi Pengaruh Kepemilikan INstitusional pada Manajemen Laba. E-Journal Akuntansi Universitas Udayana, 15(2), 1595-1622. https://doi.org/http://dx.doi.org/10.1093/clipsy/bpi010

Farouk, M. A., \& Bashir, N. M. (2017). Ownership Structure and Earnings Management of Listed Conglomerates in Nigeria. Journal of Accounting and Finance (IPjAF), 1(4), 42-54. Retrieved from http://ipjaf.omjpalpha.com/index.php/ipjaf/article/view/27

Harmana, I. M. D., \& Suardana, K. A. (2014). Pengaruh Pajak Tangguhan dan Tax to Book Ratio terhadap Kinerja Perusahaan. E-Jurnal Akuntansi Universitas Udayana, 6(3), 468-480. https:/ / doi.org/ ISSN 2302-8556

Hassanpour, S., \& Ardakani, M. N. (2017). The Effect of Pre-bankruptcy Financial Distress on Earnings Management Tools. International Review of Management and Marketing, 7(3), 213-219.

Inkiriwang, K. G. (2017). Perspektif Hukum terhadap Upaya Penghindaran Pajak oleh Suatu Badan Usaha. Lex et Societatis, 5(4), 13-18.

Iqball, A. (2010). The effect of corporate governance on earnings management around UK rights issues. International Journal of Managerial Finance, 6(3), 168189.

Jensen, M. C., \& Meckling, W. H. (1976). Theory of The Firm: Managerial Behavior Agency Costs and Ownership Structure. Journal of Financial Economics, 3, 305-360. https://doi.org/10.1016/0304-405X(76)90026-X

Kodriyah. (2015). Pengaruh Kepemilikan Institusional, Ukuran Perusahaan, Leverage, dan Good Corporate Governance terhada[ Manajemen Laba. Jurnal Akuntansi, 2(1).

Kusumawardani, N. F., \& Dewi, R. R. (2017). Motivasi Bonus, Pajak, Dan Utang 
Dalam Tindakan Manajemen Laba (Studi Perusahaan Manufaktur Yang Terdaftar Di Bursa Efek Indonesia Periode 2013-2015). Media Riset Akuntansi, Auditing Dan Informasi, 16(1), 79. https:// doi.org/10.25105/mraai.v16i1.2072 Laily, N. (2016). The Effects of Good Corporate Governance and Audit Quality on Earnings Management. Journal of Accounting and Business Education, 1(1), 98110.

Larastomo, J., Perdana, H. D., Triatmoko, H., \& Sudaryono, E. A. (2016). Pengaruh Tata Kelola Perusahaan dan Penghindaran Pajak Terhadap Manajemen Laba Pada Perusahaan Manufaktur di Indonesia. Esensi Jurnal Bisnis Dan Manajemen, 6(1), 63-74. https://doi.org/10.15408/ess.v6i1.3121

Lemma, T. T., Negash, M., Mlilo, M., \& Lulseged, A. (2018). Institutional ownership, product market competition, and earnings management: Some evidence from international data. Journal of Business Research, 90, 151-163. https://doi.org/10.1016/j.jbusres.2018.04.035

Lestari, G. A. W., \& Putri, I. G. A. . A. D. (2017). Pengaruh Corporate Governance, Koneksi Politik dan Leverage Terhadap Penghindaran Pajak. E-Jurnal Akuntansi Universitas Udayana, 18(3), 2028-2054.

M., A. M., \& Own, B. A.-. (2017). Earnings Management and Banks Performance: Evidence from Europe. International Journal of Academic Research in Accounting, Finance and Management Sciences, 7(4), 134-145. https://doi.org/10.6007/ijarafms/v7-i4/3444

Mahadewi, A. A. I. S., \& Krisnadewi, K. A. (2017). Pengaruh Kepemilikan Manajerial, Institusional dan Proporsi Dewan Komisaris Independen pada Manajemen Laba. E-Jurnal Akuntansi Universitas Udayana, 18(1), 443-470.

Man, C. keung, \& Wong, B. (2013). Corporate governance and earnings management: A survey of literature. Journal of Applied Business Research, 29(2), 391-418. https:// doi.org/10.19030/jabr.v29i2.7646

Nugroho, S., \& Darsono. (2015). Pengaruh Kompensasi, Kepemilikan Manajerial, Diversifikasi Perusahaan dan Ukuran KAP terhadap Manajemen Laba. Diponegoro Journal of Accounting, 4(3), 1-13. https://doi.org/10.1016/j.polymer.2003.08.024

Oktaviani, H. D. (2014). Pengaruh Ukuran Dewan Direksi, Proporsi Dewan Komisaris Independen, Dan Ukuran Komite Audit Terhadap Praktik Manajemen Laba Pada Perusahaan Farmasi Yang Terdaftar Di BEI Tahun 2009-2014. Jurnal Akuntansi, 1-24.

Pong, X., Brahmana, R. K., Waliuddin, M., \& Razali, M. (2014). Malaysian Listed Firm ' s Tax Avoidance: Anothe $r$ Earnings Management Strategy? Corporate Tax Revenues in Malaysia. International Journal of Academic Research in Business \& Social Sciences, 9(2), 1-9. https://doi.org/10.6007/IJARBSS/v9-i2/5597

Prabaningrat, I. G. A. A. (2015). Pengaruh Good Corporate Governance Dan Konservatisme Akuntansi Pada Manajemen Laba. E-Jurnal Akuntansi Universitas Udayana, 3(8), 663-676.

Prastiti, A., \& Meiranto, W. (2013). Pengaruh Karakteristik Dewan Komisaris Dan Ukuran Perusahaan Terhadap Manajemen Laba, 2, 1-12.

Putra, H. A., \& Ardiyanto, M. D. (2017). Pentingnya Kualitas Informasi Internal terhadap Penghindaran Pajak. Diponegoro Journal of Accounting, 6(3), 1-14. 
Putri, A. (2010). Perkembangan Akuntansi di Indonesia Anisa Putri dosen Akuntansi Fakultas Ekonomi UNISMA. Jurnal Perkembangan Akuntansi, 2(1998), 38-49.

Rani, S., Susetyo, D., \& Fuadah, L. L. (2018). The effects of the corporate's characteristics on tax avoidance moderated by earnings management (Indonesian evidence). Journal of Accounting, Finance and Auditing Studies, 4(3), 149-169.

Sari, D. A., Halim, E. H., \& Fathoni, A. F. (2008). Pengaruh Mekanisme Good Corporate Governance dan Financial Distress terhadap Earning Management pada Perusahaan Manufaktur yang Terdaftar di BEI. Jurnal Online Mahasiswa Fakultas Ekonomi Universitas Riau, 1-15.

Scott, W. R. (2018). Financial Accounting Theory (7th ed.). Ontario: Prentice Hall Canana Inc.

Siew Yee, C., Sharoja Sapiei, N., \& Abdullah, M. (2018). Tax Avoidance, Corporate Governance and Firm Value in The Digital Era. Journal of Accounting and Investment, 19(2). https:/ / doi.org/10.18196/jai.190299

Taco, C., \& Ilat, V. (2016). Pengaruh Earning Power, Komisaris Independen, Dewan Direksi, Komite Audit dan Ukuran Perusahaan Terhadap manajemen Laba Pada Perusahaan Manufaktur Yang Terdaftar di Bursa Efek Indonesia. Jurnal Emba: Jurnal Riset Ekonomi, Manajemen, Bisnis Dan Akuntansi, 4(4), 873-884.

Tanjung, M. (2015). The role of good corporate governance in minimizing earning management to increase value of firm. International Journal of Scientific $\mathcal{E}$ Technology Research, 4(09), 21-27.

Thai Ha, N. T., \& Quyen, P. G. (2017). The relationship between state ownership and tax avoidance level: empirical evidence from Vietnamese firms. Journal of Asian Business Strategy, 7(1), 1-12. https://doi.org/10.18488/journal.1006/2017.7.1/1006.1.1.12

Uwuigbe, U., \& Olusanmi, O. (2011). An Empirical Examination of the Relationship between Ownership Structure and the Performance of Firms in Nigeria. International Business Research, 5(1), 208-215. https://doi.org/10.5539/ibr.v5n1p208

Watts, \& Zimmerman. (1990). Positive Accounting Theory: A Ten Year Perspective. The Accounting Review, 65, 131-156.

Wiranata, Y. A., \& Nugrahanti, Y. W. (2013). Pengaruh Struktur Kepemilikan Terhadap Profitabilitas Perusahaan Manufaktur di Indonesia. Jurnal Akuntansi Dan Keuangan, 15(1), 15-26. https://doi.org/10.9744/jak.15.1.1526

Wiryadi, A., \& Sebrina, N. (2013). Pengaruh Asimetri Informasi, Kualitas Audit, dan Struktur Kepemilikan terhadap Manajemen Laba. Jurnal Wahana Riset Akuntansi, 1(2), 155-180. 